Article

\title{
Microwave-Assisted Kinetic Resolution of Homochiral $(Z)$-Cyclooct-5-ene-1,2-diol and (Z)-2-Acetoxycyclooct-4-enyl Acetate Using Lipases
}

\section{Hervé Rouillard, Emmanuel Deau, Lisianne Domon, Jean-René Chérouvrier, Marianne Graber and Valérie Thiéry *}

Université de La Rochelle, UMR CNRS 7266 LIENSs, Avenue Crépeau, La Rochelle 17042, France; E-Mails: herve.rouillard@univ-lr.fr (H.R.); emmanuel.deau@univ-orleans.fr (E.D.);

lisianne.domon@univ-lr.fr (L.D.); jcherouv@univ-lr.fr(J.-R.C.); marianne.graber@univ-lr.fr (M.G.)

* Author to whom correspondence should be addressed; E-Mail: valerie.thiery@univ-lr.fr; Tel.: +33-546-458-276; Fax: +33-546-458-265.

Received: 30 May 2014; in revised form: 21 June 2014 / Accepted: 30 June 2014 /

Published: 2 July 2014

\begin{abstract}
Over the last decade, the use of biocatalysts has become an attractive alternative to conventional chemical methods, especially for organic synthesis, due to their unusual properties. Among these enzymes, lipases are the most widely used, because they are cheap, easily available, cofactor-free, and have broad substrate specificity. Combined to microwave heating in non-aqueous medium, recent results suggest that irradiation may influence the enzyme activity. This Communication reports the benefits of lipases and the microwave irradiation on the kinetic resolution of racemic homochiral $(Z)$-cyclooct-5-ene1,2-diol and (Z)-2-acetoxycyclooct-4-enyl acetate. In order to best achieve the kinetic resolution, different parameters were studied including the type of lipase, the temperature, the impact of microwave power compared to conventional heating. Optimization of the reaction parameters lead to the obtainment of highly enriched or enantiopure diols and diesters in a clean, efficient and safe way.
\end{abstract}

Keywords: biocatalysis; microwave irradiation; lipase; homochiral diols; kinetic resolution 


\section{Introduction}

Enantiomerically pure vicinal diols are versatile chemical scaffolds for the production of flavors and fragances. As part of our work on the enantioselective synthesis of methyl jasmonate derivatives from optically active bicyclo[3.3.0] octane derivatives by transannular cyclization, we first needed to prepare enantiopure homochiral $(1 R, 2 R)$ - and $(1 S, 2 S)$-5-cyclooctene-1,2-diols. In recent years, the development of biocatalysts for organic synthesis has become an attractive alternative to conventional chemical methods. Among those biocatalysts, lipases have become very popular in both academic and industrial sectors because they are inexpensive, easily available, cofactor free and have a broad substrate specificity [1]. We decided to focus our interest on microwave-assisted lipase- mediated kinetic resolution involving CaLB (lipase B from Candida antartica) or PS (Pseudomonas cepacia)-catalyzed acetylation of diol. The use of microwave irradiation in biocatalysis can enhance the enzyme activity, for example in resolution reaction, in specific oxido-reduction reaction or hydrolysis. Combined to non-aqueous medium, recent results suggest that microwave irradiation can have also influence the enzyme stability and activity, in addition to altering/enhancing reaction rates and/or enantioselectivities, called non-thermal microwave effects [2-8]. However, the exact role of microwave irradiation on enzymes still remains unresolved [9]. To better comprehend the influence of microwave irradiation on a biocatalyst, we decided to compare the lipase-catalyzed resolution of difunctionalized compounds, under conventional and microwave irradiation heating. We report herein our studies on microwave assisted lipase resolution of homochiral $(1 R, 2 R)$ - and $(1 S, 2 S)$-5-cyclooctene1,2-diols 2 and their diesters 4 , by varying the irradiation power and reaction temperature.

\section{Results and Discussion}

In the context of the growing general interest for reducing energy costs, heating chemical reactions under microwave irradiation is a useful approach for achieving higher reaction kinetics and synthesizing cleaner products [10-13]. In combination with microwave technology and lipases, we wished to examine the synthesis of chiral cyclooctenic diols and diesters starting from cycloocta-1,5-diene using microwave technology. rac-Diols $\mathbf{2}$ and rac-diacetates $\mathbf{4}$ were initially prepared from cycloocta-1,5-diene in a three-steps sequence including epoxidation, ring opening with aqueous sulfuric acid, followed by acetylation with acetic anhydride (Scheme 1) [14,15].

Scheme 1. Epoxidation and hydrolysis of cycloocta-1,5-diene leading to racemic diols 2 and acetylation affording diacetates 4 .

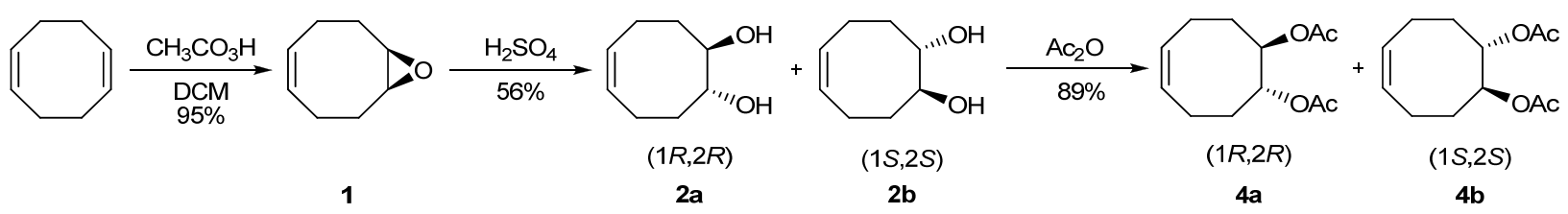

The preparation of optically active 5-cyclooctene-1,2-diol $\mathbf{2}$ was first conceived by using microwave-assisted lipase-catalyzed desymmetrization of meso-symmetric diol 2 using vinyl acetate as the acylating agent in THF as solvent rather than isooctane or 2-methylbutan-2-ol, that gave lower results. In order to perform the reaction under microwave irradiation, we decided to choose 
thermostable immobilized lipases capable of withstanding microwave irradiation: Novozyme $435^{\circledR}$ (CaLB immobilized on acrylic resin) and PS-D (Pseudomonas cepacia immobilized on diatomite). The goal was to obtain an enantioselective enhancement with immobilized lipases, as previous studies performed in our laboratory showed that resolution of rac-diol 2 with free Pseudomonas cepacia lipase at $55{ }^{\circ} \mathrm{C}$ in THF during 7 days afforded with a good conversion rac-monoacetate 3 (47\%, $0 \%$ ee) and rac-diol 2 (51\%, 0\% ee) but with no selectivity at all. Indeed, by immobilization of enzymes onto solid supports, enhanced enzyme activity, selectivity, stability, and reusability in organic media may be achieved compared to the native enzyme [16].

Performed at $35{ }^{\circ} \mathrm{C}$ under conventional heating immobilized CaLB-enzymatic acylation of rac-diol (2) afforded after 3 weeks $28 \%$ of $(1 R, 2 R)$-monoacetate 3a (42\% ee) and $6 \%$ of $(1 S, 2 S)$-diacetate $4 \mathbf{b}$ with an excellent $99 \%$ ee. A higher temperature $\left(50{ }^{\circ} \mathrm{C}\right)$ led after 7 days to modest yields of monoacetate 3a and a real enhancement of yield for diacetate $\mathbf{4 b}(20 \%$ with ee $>99 \%$ ) (Scheme 2 and Table 1).

Scheme 2. Enantioselective acetylation of diol (2) using immobilized CaLB lipase and vinyl acetate by classical heating at various temperatures.<smiles>O[C@H]1CCC=CCC[C@H]1O</smiles>

$(1 R, 2 R)$

2a<smiles>O[C@H]1CCC=CCC[C@H]1O</smiles>

$(1 S, 2 S)$

2b
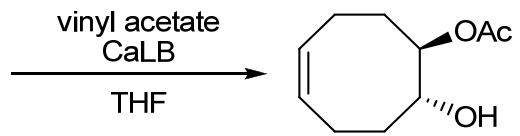

$(1 R, 2 R)$

3a

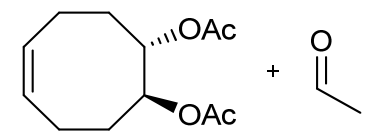

$(1 S, 2 S)$

4b

Table 1. Enantioselective acetylation of diol (2) using immobilized CaLB lipase and vinyl acetate by classical heating at various temperatures.

\begin{tabular}{ccccccc}
\hline Heating Mode & $\begin{array}{c}\text { Temperature } \\
\left({ }^{\circ} \mathbf{C}\right)\end{array}$ & Time & $\begin{array}{c}\text { Monoacetate 3a } \\
\text { Yield (\%) }\end{array}$ & ee (\%) & $\begin{array}{c}\text { Diacetate 4b } \\
\text { Yield (\%) }\end{array}$ & ee (\%) \\
\hline Classical & 35 & 3 weeks & 28 & 42 & 6 & $>99$ \\
Classical & 50 & 7 days & 30 & 50 & 20 & $>99$ \\
Classical & 50 & $14 \mathrm{~h}$ & traces & & & - \\
\hline
\end{tabular}

Under microwave irradiation at $35{ }^{\circ} \mathrm{C}(5 \mathrm{~W})$, racemic diol 2 proceeded to give $(1 R, 2 R)$-monoacetate 3a $(32 \%, 45 \%$ ee), trace amounts of $(1 S, 2 S)$-diacetate $\mathbf{4 b}(5 \%,>99 \%$ ee) and $65 \%$ of diol $\mathbf{2}$ (23\% ee). In order to study the influence of the irradiation power on the biocatalytic media, we decided to apply a constant power (up to $300 \mathrm{~W}$ ) while maintaining the temperature at $35^{\circ} \mathrm{C}$ by using a microwave oven combined with a Coolmate ${ }^{\circledR}$. We noticed an enhancement of the yield and the enantiomeric ratio of $(1 R, 2 R)$-monoacetate 3a (42\%, 67\% ee) and diol $2(51 \%, 50 \%$ ee) and only $2 \%$ of diacetate $\mathbf{4 b}(99 \%$ ee). At $50{ }^{\circ} \mathrm{C}(10 \mathrm{~W}, 14 \mathrm{~h})$ the same reaction yielded only esters: $58 \%$ of $(1 R, 2 R)$-monoacetate $3 \mathbf{a}$ with $55 \%$ ee and $37 \%$ of diacetate $\mathbf{4 b}\left(99 \%\right.$ ee). A higher temperature $\left(80{ }^{\circ} \mathrm{C}, 40 \mathrm{~W}, 14 \mathrm{~h}\right)$ afforded a decrease of diacetate yield with a lower enantiomeric excess (30\% of $\mathbf{4 b}$ with 94\% ee) (Scheme 3 and Table 2). 
Scheme 3. Enantioselective acetylation of diol 2 using immobilized CaLB with vinyl acetate lipase under microwave irradiation.

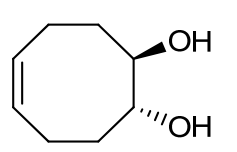

$(1 R, 2 R)$

2a

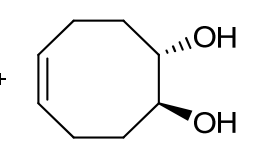

$(1 S, 2 S)$

$\mathbf{2 b}$

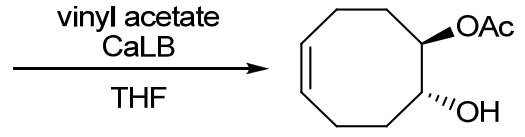

$(1 R, 2 R)$

3a

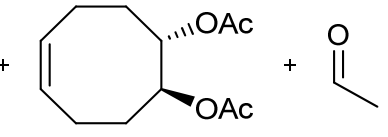

$(1 S, 2 S)$

4b

Table 2. Enantioselective acetylation of diol 2 using immobilized CaLB lipase under microwave irradiation in a large range of temperatures. * Constant power when the temperature is reached (max: $300 \mathrm{~W}, 2 \mathrm{~min}) ; * *$ Using Coolmate.

\begin{tabular}{ccccccc}
\hline \multirow{2}{*}{ Power (W) } & $\begin{array}{c}\text { Incubation } \\
\text { Time }(\mathbf{h})\end{array}$ & $\begin{array}{c}\text { Temperature } \\
\text { ( }\end{array}$ & $\mathbf{(} \mathbf{C})$ & \multicolumn{2}{c}{ Monoacetate 3a } & \multicolumn{2}{c}{ Diaceate 4b } \\
\cline { 4 - 7 } & 14 & 35 & yield (\%) & ee (\%) & yield (\%) & ee (\%) \\
\hline $5 *$ & 14 & 50 & 58 & 55 & 5 & 99 \\
$10 *$ & 14 & 80 & 55 & 57 & 30 & 99 \\
$20 *$ & 14 & 100 & - & - & - & - \\
$40 *$ & 14 & 35 & 42 & 67 & 2 & $>99$ \\
$300 * *$ & &
\end{tabular}

These results suggest that, at higher temperature $\left(100{ }^{\circ} \mathrm{C}\right)$, there is a loss of enzyme activity due to its denaturation. At $80^{\circ} \mathrm{C}$, Poojari et al., have shown that the immobilized-CalB (Novozym 435) was very stable and kept $90 \%$ of its activity after an incubation in diphenylether for $24 \mathrm{~h}$ [17]. The irradiation power appears to display a key role in enzyme properties, and best enhancement of monoacetate yield and ee was observed at $35{ }^{\circ} \mathrm{C}$ with $300 \mathrm{~W}$. Brimble et al., have shown that compared to conventional heating the microwave irradiation led to higher conversion and enantiomeric excesses, in the case of lipase-catalyzed kinetic resolution of racemic secondary alcohols through acetylation [18].

At $50{ }^{\circ} \mathrm{C}$ under conventional heating, enzyme-catalyzed acylation of rac-diol 2 with immobilized PS-D provided both $(1 S, 2 S)$-monoacetate $\mathbf{3 b}$ and $(1 R, 2 R)$-diol 2a in poor enantiomeric purity (respectively $45 \%$ ee for $\mathbf{3 b}$ and $3 \%$ ee for $\mathbf{2 a}$ ) and poor conversion (6\%). At higher temperatures $\left(80,100{ }^{\circ} \mathrm{C}\right)$, PS-D proved to be ineffective and lost all enzymatic activity. Under microwave irradiation at $50{ }^{\circ} \mathrm{C}(15 \mathrm{~W})$, lipase resolution of racemic diol 2 afforded $(1 S, 2 S)$-monoacetate $\mathbf{3 b}(41 \%$, $50 \%$ ee) and $(1 R, 2 R)$-diol $(57 \%, 35 \%$ ee). The microwave irradiation method gave a higher conversion compared to conventional heating. At $80{ }^{\circ} \mathrm{C}(35 \mathrm{~W})$, the reaction yielded $12 \%$ of $\mathbf{3 b}(35 \%$ ee) and $66 \%$ of diol with no selectivity ( $5 \%$ ee) (Scheme 4 and Table 3 ).

Scheme 4. Acetylation of diol 2 using immobilized PS lipase (PS-D).

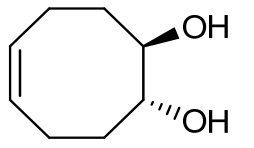

$(1 R, 2 R)$

2a

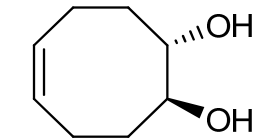

$(1 S, 2 S)$

2b

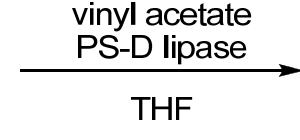

THF

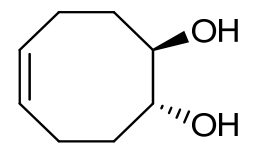

$(1 R, 2 R)$

$2 \mathrm{a}$

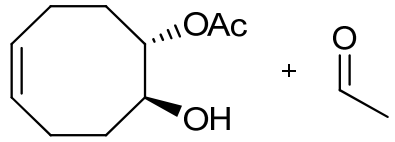

$(1 S, 2 S)$

3b 
Table 3. Acetylation of diol 2 using immobilized PS lipase (PS-D) (incubation time:14 h). Effect of the heating mode and temperature on the conversion and kinetic resolution of rac-2 into diol $\mathbf{2 a}$ and monoacetate $\mathbf{3 b}$. * Constant power when the temperature is reached (max: $300 \mathrm{~W}$ and $2 \mathrm{~min}$ ).

\begin{tabular}{ccccc}
\hline Heating Mode & Temperature $\left({ }^{\circ} \mathbf{C}\right)$ & $\begin{array}{c}\text { Diol 2a } \\
\text { ee (\%) }\end{array}$ & $\begin{array}{c}\text { Monoacetate 3b } \\
\text { yield (\%) }\end{array}$ & ee (\%) \\
\hline \multirow{3}{*}{ Classical } & 50 & 3 & 6 & 45 \\
& 80 & - & - & - \\
Microwave & 100 & - & - & - \\
& $50\left(15 \mathrm{~W}^{*}\right)$ & 35 & 41 & 50 \\
& $80(35 \mathrm{~W} *)$ & 5 & 12 & 35 \\
\hline
\end{tabular}

Noteworthy, PS-D exhibited a reverse enantiopreference for the monoacetate $(1 S, 2 S)$ compared to CaLB.

Following these preliminary results, we then investigated the lipase-catalyzed kinetic hydrolytic resolution of rac-diacetate 4 according to the Suemune procedure [19]. Instead of using PFL (Pseudomonas fluorescens lipase), we used immobilized CaLB and PS-D in order to perform later the reaction under microwave. Performed at various temperature $\left(35,50\right.$ and $\left.80{ }^{\circ} \mathrm{C}\right)$ under conventional heating CaLB-catalyzed hydrolysis of rac-diacetate (4) in phosphate buffer $(0.1 \mathrm{M}, \mathrm{pH} 7.0)$ led only to traces of monoacetate at $50{ }^{\circ} \mathrm{C}$. Compared to conventional heating, the microwave irradiation at $50{ }^{\circ} \mathrm{C}$ during $14 \mathrm{~h}$ led to a higher conversion (20\%) with excellent enantiomeric excess for monoacetate (ee: $97 \%$ for $\mathbf{3 b}(1 S, 2 S)$ ) besides diacetate $\mathbf{4 a}$ (ee: $34 \%$ ) (Scheme 5 and Table 4 ).

Scheme 5. Hydrolysis of diacetate 4 using immobilized CaLB lipase in phosphate buffer (0.1 M, pH 7). For detailed conversion and ee, see Table 4.

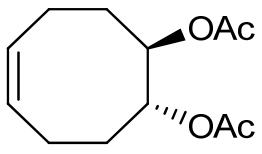

$(1 R, 2 R)$

4a

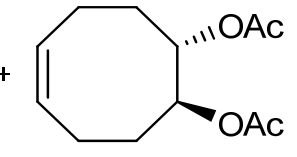

$(1 S, 2 S)$

4b

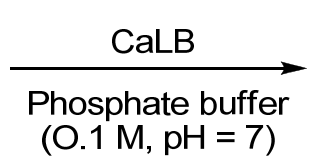

Phosphate buffer
$(\mathrm{O} .1 \mathrm{M}, \mathrm{pH}=7)$

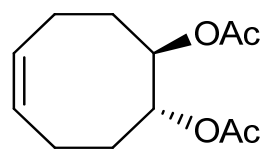

$(1 R, 2 R)$

4a

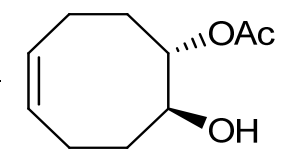

$(1 S, 2 S)$

3b

Table 4. Hydrolysis of rac-diacetate 4 using immobilized CaLB lipase (incubation time: $14 \mathrm{~h}$ ). Effect of the heating mode and temperature on the conversion and kinetic resolution of rac-4 into diacetate $\mathbf{4 a}$ and monoacetate $\mathbf{3 b}$. ${ }^{*}$ Constant power when the temperature is reached (max: $300 \mathrm{~W}$ and $2 \mathrm{~min}$ ).

\begin{tabular}{ccccc}
\hline Heating Mode & Temp. $\left({ }^{\circ} \mathbf{C}\right)$ & Conversion & Diacetate 4a ee (\%) & Monoacetate 3b ee (\%) \\
\hline \multirow{3}{*}{ Classical } & 35 & - & - & - \\
& 50 & Traces & - & - \\
& 80 & - & - & - \\
Microwave & $35\left(1-5 \mathrm{~W}^{*}\right)$ & - & - & - \\
& $50\left(5 \mathrm{~W}^{*}\right)$ & $20 \%$ & {$[\alpha]_{\mathrm{D}}=+29^{\circ}$} & {$[\alpha]_{\mathrm{D}}=+6^{\circ}$} \\
& $80\left(10 \mathrm{~W}^{*}\right)$ & - & - & - \\
\hline
\end{tabular}


Given the promising results obtained during the first enantioenrichment of rac- $\mathbf{4}$ with $\mathrm{CaLB}$, the recovered $(1 R, 2 R)$-diacetate 4 a with $34 \%$ ee was submitted twice to the same enzymatic hydrolysis under microwave irradiation $\left(2 \times 14 \mathrm{~h}, 50{ }^{\circ} \mathrm{C}, 5 \mathrm{~W}\right)$. Enantiopure $(1 R, 2 R)$-diacetate $4 \mathrm{a}$ was obtained in $49 \%$ yield from rac-4 (Scheme 6 and Table 5).

Scheme 6. Sequential enantioenrichment of diacetate $\mathbf{4 a}$.<smiles>CC(=O)O[C@@H]1CC/C=C\CC[C@H]1OC(C)=O</smiles>

$(1 R, 2 R)$

$4 a$<smiles>CC(=O)O[C@H]1CC/C=C\CC[C@H]1OC(C)=O</smiles>

(1S,2S)

4b

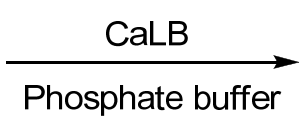

$(0.1 \mathrm{M}, \mathrm{pH}=7)$ $50^{\circ} \mathrm{C}(\mu \mathrm{w}, 5 \mathrm{~W}), 14 \mathrm{~h}$

Sequential enantioenrichment (3 times)<smiles>CC(=O)O[C@@H]1CC/C=C\CC[C@H]1OC(C)=O</smiles>

$(1 R, 2 R)$

$4 a$

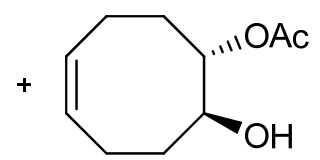

(1S,2S)

3b

Table 5. Sequential enantioenrichment of diacetate $\mathbf{4 a}$.

\begin{tabular}{|c|c|c|c|c|c|c|}
\hline & Yield (\%) & $\begin{array}{c}\text { Monoacetate 3b } \\
\text { ee (\%) } \\
\end{array}$ & {$[\alpha]_{D}$} & yield (\%) & $\begin{array}{c}\text { Diacetate 4a } \\
\text { ee }(\%) \\
\end{array}$ & {$[\alpha]_{D}$} \\
\hline 1st enrichment & 20 & 97 & $+5.8^{\circ}$ & 80 & 34 & $+25^{\circ}$ \\
\hline 2nd enrichment & 41 & 98 & $+6^{\circ}$ & 57 & 72 & $+57^{\circ}$ \\
\hline 3rd enrichment & 51 & 97 & $+5.7^{\circ}$ & 49 & $>99$ & $+81^{\circ}$ \\
\hline
\end{tabular}

CaLB and the PS-D were finally compared for their ability to carry out an effective kinetic resolution of rac-4 diester. The hydrolysis using PS-D was conducted in the same manner. In classical conditions whatever the temperature $\left(35,50,80^{\circ} \mathrm{C}\right)$ and the reaction time $(14 \mathrm{~h}, 7$ days $)$, in no case conversion to monoacetate 3 was observed. Interestingly, under microwave irradiation at $50{ }^{\circ} \mathrm{C}(14 \mathrm{~h})$, rac-4 was desymmetrized into $(1 R, 2 R)$ monoacetate $\mathbf{3 a}$ with $81 \%$ ee and $(1 S, 2 S)$-diacetate $\mathbf{4} \mathbf{b}(28 \%$ ee), highlighting a non-thermal effect (Scheme 7 and Table 6).

The microwave-assisted hydrolysis seems to enhance the enzyme activity compared to classical heating. Comparing the results with Suemune et al. [19], the CaLB seems to be a convenient enzyme in microwave irradiation resulting in the obtention of enantiopure monoacetate $\mathbf{3 a}$ in a quick and clean way. However, the same reaction with PS-D needed to be optimized to obtain a better ee.

Scheme 7. Hydrolysis of diacetate 4 using PS-D lipase in phosphate buffer (0.1 M, pH 7).

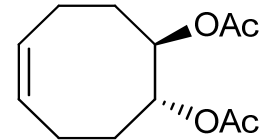

$(1 R, 2 R)$

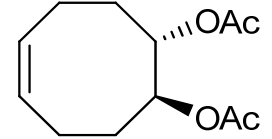

$(1 S, 2 S)$

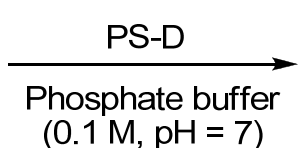

$(0.1 \mathrm{M}, \mathrm{pH}=7)$

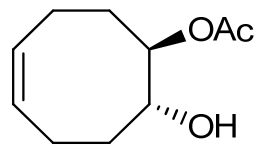

$(1 R, 2 R)$<smiles>CC(=O)O[C@H]1CCC=CCC[C@H]1OC(C)=O</smiles>

$(1 S, 2 S)$

3a 
Table 6. Hydrolysis of diacetate 4 using PS-D lipase (incubation time: 14 h). Effect of the heating mode and temperature on the conversion and kinetic resolution of rac-4 into monoaceate 3a and diester $\mathbf{4 b}$. * Constant power when the temperature is reached (max: $300 \mathrm{~W}$ and $2 \mathrm{~min})$.

\begin{tabular}{ccccc}
\hline Mode of Heating & Temp. $\left({ }^{\circ} \mathbf{C}\right)$ & Conversion & $\begin{array}{c}\text { Monoacetate 3a } \\
\text { ee (\%) }\end{array}$ & $\begin{array}{c}\text { Diacetate 4b } \\
\text { ee (\%) }\end{array}$ \\
\hline \multirow{2}{*}{ Classical } & 35 & - & - & - \\
& 50 & - & - & - \\
\hline \multirow{4}{*}{ Microwave } & 50 & - & - & - \\
& $50\left(1-5 \mathrm{~W}^{*}\right)$ & - & - & - \\
& & $10 \%$ & 81 & 28 \\
& $80\left(10 \mathrm{~W}^{*}\right)$ & - & $-\alpha]_{\mathrm{D}}=-4^{\circ}$ & {$[\alpha]_{\mathrm{D}}=-24^{\circ}$} \\
\hline
\end{tabular}

Finally, the isolated enantiopure monoacetates $\mathbf{3 a}, \mathbf{3 b}$ and diacetates $\mathbf{4 a}$ and $\mathbf{4 b}$ were then quantitatively converted into $(1 R, 2 R)$-diol $\mathbf{2 a}$ and $(1 S, 2 S)$-diol $\mathbf{2 b}$ with $>99 \%$ ee by methanolysis [7] (Scheme 8).

Scheme 8. Isolation of enantiopure diols $\mathbf{2 a}$ and $\mathbf{2 b}$ by methanolysis of monoacetate $\mathbf{3 a}$ and diacetate $\mathbf{4 b}$.

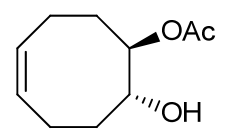

$(1 R, 2 R)$

3a

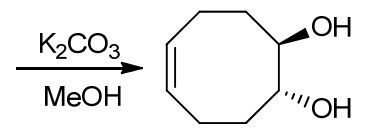

$(1 R, 2 R)$

$\mathbf{2 a}$

$99 \%$ $[\alpha]_{D}^{20}=-20,9^{\circ}\left(c=1.00 \mathrm{CHCl}_{3}\right)$

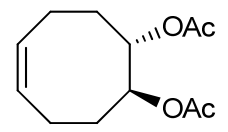

(1S,2S)

$4 b$

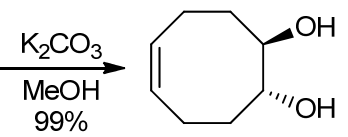

(1S,2S)

2b

$99 \%$

$[\alpha]_{D}^{20}=+18.2^{\circ}\left(\mathrm{c}=1.00 \mathrm{CHCl}_{3}\right)$

\section{Experimental Section}

\subsection{General Information}

Lipases from Pseudomonas cepacia (immobilized on diatoms MKBB3465, $500 \mathrm{PLU}^{-1}$ ) and Candida antarctica (immobilized on acrylic resin 077K1155, 10,000 $\mathrm{PLU}^{-1}$ Novozym $435^{\circledR}$ or free form) were purchased from Sigma Aldrich (Sigma-Aldrich Chemie S.a.r.1., Saint Quentin Fallavier, France). All other chemicals were purchased from Sigma Aldrich and were used without further purification except in the case of vinyl acetate which was used after fresh distillation.

IR spectra were recorded on a Perkin-Elmer Spectrum 100 IRFT-ATR instrument (Perkin-Elmer, Courtaboeuf-Les Ulis, France). ${ }^{1} \mathrm{H}$ - and ${ }^{13} \mathrm{C}-\mathrm{NMR}$ were recorded on a JEOL JNM LA400 (400 MHz) spectrometer (JEOL SAS Europe, Croissy Sur Seine, France). Chemical shifts $(\delta)$ are reported in parts per million ( $\mathrm{ppm})$ downfield from tetramethylsilane (TMS) which was used as internal standard. Coupling constants $\mathrm{J}$ are given in Hz. The high resolution mass spectra (HRMS) were recorded on a Varian MAT311 spectrometer (Agilent Technologies SAS, Les Ulis, France) in the Centre Régional de Mesures Physiques de l'Ouest (CRMPO), Université de Rennes. Analytical thin layer chromatography 
(TLC) was performed on Merck Kieselgel 60 F254 aluminum packed plates (Merck KgaA, Darmstadt, Germany).

Enantiomeric ratios were determined by gas chromatography (Agilent 7890A, Agilent Technologies SAS, Les Ulis, France) equipped with an autosampler (7688B) and flame ionization detector (FID). For the experiment, a CP-Chirasil-Dex $(0.25 \mathrm{~mm} \times 25 \mathrm{~m} \times 0.25 \mu \mathrm{m}$, Chromopack, Agilent Technologies SAS, Les Ulis, France) column was used. The injector and the detector were kept at $180{ }^{\circ} \mathrm{C}$. Nitrogen was used as gas carrier at a flow of $1.5 \mathrm{~mL} / \mathrm{min}$. Hydrogen, air and nitrogen were supplied to the FID at $35 \mathrm{~mL} \cdot \mathrm{min}^{-1}, 350 \mathrm{~mL} \cdot \mathrm{min}^{-1}$ and $25 \mathrm{~mL} \cdot \mathrm{min}^{-1}$ respectively. The products are analyzed at $110^{\circ} \mathrm{C}$. The enantiomeric ratio and yields were calculated by taking the average of two duplicates, with an error $<2 \%$.

High performance liquid chromatography (HPLC) was carried out in a Waters 600 s system (Water SAS, Guyancourt, France) combined with an autosampler (Waters 717 plus). A Chiralpak-AD column (amylose tris-(3,5-dimethylphenylcarbamate) coated on $10 \mu \mathrm{m}$ silica-gel, Daicel Chemical, $250 \times 4.6 \mathrm{~mm}$, Chiral Technologies Europe SAS, Illkirch, France) is used. Eluent was $n$-heptane/EtOH, 9/1 at a flowrate of $1 \mathrm{~mL} \cdot \mathrm{min}^{-1}$. Products were analyzed using a differential refractometer (Waters 410). Optical rotations were measured on a Perkin Elmer 341 polarimeter.

Microwave reactions were conducted using a CEM Discover ${ }^{\circledR}$, single mode operating system (CEM France, Saclay, France) working at $2.45 \mathrm{GHz}$, with a programmable power ranging from 1 to $300 \mathrm{~W}$. The microwave can be equipped with a Coolmate ${ }^{\circledR}$ system allowing reactions with high power input (up to $300 \mathrm{~W}$ ) while maintaining the reaction media at $35^{\circ} \mathrm{C}$. This system is cooled by a cryogenic fluid (Galden HT-55 ${ }^{\circledR}$, BT Electronics, Les Ulis, France). In closed vessel mode, microwave irradiation experiments were carried out using a single-mode microwave instrument (Initiator, Biotage, Uppsala, Sweden) working at $2.45 \mathrm{GHz}$, with a power programmable from 1 to $450 \mathrm{~W}$ (0-20 bars).

\section{2. (Z)-(1S,8R)-9-Oxa-Bicyclo[6.1.0]Non-4-Ene (1)}

Under inert atmosphere, to a solution of cycloocta-1,5-diene (20 g, $0.161 \mathrm{~mol})$ and sodium carbonate $(117.6 \mathrm{~g}, 1.11 \mathrm{~mol})$ in dichloromethane $(560 \mathrm{~mL})$ stirred at $0{ }^{\circ} \mathrm{C}$ was added dropwise a solution of peracetic acid $(42.7 \mathrm{~mL}, 0.222 \mathrm{~mol})$ in dichloromethane $(500 \mathrm{~mL})$ during $2 \mathrm{~h}$. The mixture was stirred for $8 \mathrm{~h}$ at $0{ }^{\circ} \mathrm{C}$ and $12 \mathrm{~h}$ at room temperature. The mixture was quenched with $500 \mathrm{~mL}$ of water and extracted with $(3 \times 250 \mathrm{~mL})$ of dichloromethane. The organic layers were dried with magnesium sulfate anhydrous and concentrated under reduced pressure. The crude residue was purified by column chromatography (silica gel, petroleum ether/ethyl acetate 90/10) to provide the (Z)-(1S,8R)-9-oxa-bicyclo[6.1.0]non-4-ene $\left(1,5.697 \mathrm{~g}, 67 \%\right.$ yield) as a colorless oil; $v_{\max }\left(\mathrm{cm}^{-1}\right): 3003$, 2906, 2887, 1655, 1445, 1428, 1228, 1669, 1099, 1039, 934, 762, 743; ${ }^{1} \mathrm{H}-\mathrm{NMR}\left(\mathrm{CDCl}_{3}\right): \delta_{\mathrm{H}} 5.56-5.60$ $(2 \mathrm{H}, \mathrm{m}, \mathrm{C} \underline{\mathrm{H}}=\mathrm{C} \underline{\mathrm{H}}), 3.00-3.02(2 \mathrm{H}, \mathrm{m}, \mathrm{C} \underline{\mathrm{HC}} \underline{\mathrm{H}}), 2.41-2.47\left(2 \mathrm{H}, \mathrm{m}, \mathrm{C}_{2}\right), 2.08-2.15\left(2 \mathrm{H}, \mathrm{m}, \mathrm{C}_{2}\right)$, $1.98-2.17\left(4 \mathrm{H}, \mathrm{m}, 2 \times \mathrm{CH}_{2}\right) ;{ }^{13} \mathrm{C}-\mathrm{NMR}\left(\mathrm{CDCl}_{3}\right): \delta_{\mathrm{C}} 128.6,56.2,27.8,23.4$.

\section{3. (Z)-Cyclooct-5-en-1,2-diol (2)}

Under inert atmosphere, to the $(Z)-(1 S, 8 R)$-9-oxabicyclo[6.1.0]non-4-ene (1, $5.697 \mathrm{~g}, 45.9 \mathrm{mmol})$ vigorously stirred was added a solution of sulfuric acid $2 \mathrm{M}(25.3 \mathrm{~mL}, 50.47 \mathrm{mmol})$. After $4 \mathrm{~h}$ under stirring, the mixture was extracted with $3 \times 75 \mathrm{~mL}$ of ethyl acetate. The organic layers were washed 
with a saturated solution of sodium hydrogenocarbonate $(40 \mathrm{~mL})$, brine $(40 \mathrm{~mL})$, dried with magnesium sulfate and concentrated under vacuum. The crude residue was purified by column chromatography (silica gel, petroleum ether/ethyl acetate 60/40) to give the rac-(Z)-cyclooct-5-en-1,2diol (2, $3.691 \mathrm{~g}, 57 \%$ yield) as a colorless oil; $v_{\max }\left(\mathrm{cm}^{-1}\right)$ : 3362, 3014, 2964, 2861, 1651, 1427, 1429, 1400, 1271, 1202, 1010, 994, 976, 947, 868, 732, 719; ${ }^{1} \mathrm{H}-\mathrm{NMR}\left(\mathrm{CDCl}_{3}\right): \delta_{\mathrm{H}} 5.55-5.59(2 \mathrm{H}, \mathrm{m}$, $\mathrm{C} \underline{\mathrm{H}}=\mathrm{C} \underline{\mathrm{H}}), 3.57-3.61(4 \mathrm{H}, \mathrm{m}, \mathrm{C} \underline{\mathrm{HOH}} \underline{\mathrm{H}} \underline{\mathrm{HO}} \underline{\mathrm{H}}), 2.29-2.35\left(2 \mathrm{H}, \mathrm{m}, \mathrm{C}_{2}\right), 2.00-2.12\left(4 \mathrm{H}, \mathrm{m}, 2 \times \underline{\mathrm{C}}_{2}\right)$, 1.52-1.58 $\left(2 \mathrm{H}, \mathrm{m}, \mathrm{C}_{2}\right)$; ${ }^{13} \mathrm{C}-\mathrm{NMR}\left(\mathrm{CDCl}_{3}\right): \delta_{\mathrm{C}} 128.9$, 73.8, 33.1, 22.6; HRMS: calculated for $\mathrm{C}_{8} \mathrm{H}_{14} \mathrm{O}_{2}[\mathrm{M}]^{+}:$142.09938, Found: 142.1001 (5 ppm).

\section{4. (1R,2R)-(Z)-1-Hydroxycyclooct-4-enyl Acetate (3a)}

Compound 3a was obtained as a colorless oil $[\alpha]_{D}^{20}-3.0^{\circ}\left(c 1.00 \mathrm{CHCl}_{3}\right) \cdot v_{\max }\left(\mathrm{cm}^{-1}\right): 3449,3012$, 2936, 1717, 1654, 1430, 1235, 1030, 971, 933, 720; ${ }^{1} \mathrm{H}-\mathrm{NMR}\left(\mathrm{CDCl}_{3}\right): \delta_{\mathrm{H}} 5.59-5.69(2 \mathrm{H}, \mathrm{m}, \mathrm{C} \underline{\mathrm{H}}=\mathrm{C} \underline{\mathrm{H}})$, $4.95(1 \mathrm{H} \mathrm{dt}, J=8.8 \mathrm{~Hz}, 4.0 \mathrm{~Hz}, \mathrm{C} \underline{\mathrm{HOAc}}), 3.90(1 \mathrm{H}, \mathrm{dt}, J=2.1 \mathrm{~Hz}, \mathrm{C} \underline{\mathrm{HOH}}), 2.54(1 \mathrm{H}, \mathrm{s}, \mathrm{O} \underline{\mathrm{H}}), 2.38-2.42$ (m, $\left.2 \mathrm{H}, \underline{\mathrm{C}}_{2}\right), 2.04-2.25\left(\mathrm{~m}, 7 \mathrm{H}, 2 \times \underline{\mathrm{C}}_{2}\right.$ and $\left.\underline{\mathrm{C}}_{3}\right), 1.68-1.75\left(\mathrm{~m}, 2 \mathrm{H}, \underline{\mathrm{C}}_{2}\right) ;{ }^{13} \mathrm{C}-\mathrm{NMR}\left(\mathrm{CDCl}_{3}\right): \delta_{\mathrm{C}}$ 170.9, 129.6, 128.6, 77.3, 72.1, 32.8, 30.0, 22.8, 22.8, 21.2. GC: Cromopack column $\mathrm{t}_{\mathrm{R}}=59.7 \mathrm{~min}$ HRMS: calcd for $\mathrm{C}_{8} \mathrm{H}_{14} \mathrm{O}_{2}\left[\mathrm{M}-\mathrm{CH}_{2} \mathrm{CO}\right]^{+}$: 142.09938, Found: 142.0993 (0 ppm).

\section{5. (1S,2S)-(Z)-1-Hydroxycyclooct-4-enyl Acetate (3b)}

Compound 3b was obtained as a colorless oil. $[\alpha]_{D}^{20}+3.2^{\circ}\left(c 1.00 \mathrm{CHCl}_{3}\right) \cdot v_{\max }\left(\mathrm{cm}^{-1}\right): 3449,3012$, 2936, 1717, 1654, 1430, 1235, 1030, 971, 933, 720; ${ }^{1} \mathrm{H}-\mathrm{NMR}\left(\mathrm{CDCl}_{3}\right): \delta_{\mathrm{H}} 5.59-5.69(2 \mathrm{H}, \mathrm{m}, \mathrm{C} \underline{\mathrm{H}}=\mathrm{C} \underline{\mathrm{H}})$, $4.95(1 \mathrm{H} \mathrm{dt}, J=8.8 \mathrm{~Hz}, 4.0 \mathrm{~Hz}, \mathrm{C} \underline{\mathrm{HOAc}}), 3.90(1 \mathrm{H}, \mathrm{dt}, J=2.1 \mathrm{~Hz}, \underline{\mathrm{HOH}}), 2.54(1 \mathrm{H}, \mathrm{s}, \mathrm{OH}), 2.38-2.42$ (m, $\left.2 \mathrm{H}, \underline{\mathrm{C}}_{2}\right), 2.04-2.25\left(\mathrm{~m}, 7 \mathrm{H}, 2 \times \underline{\mathrm{CH}}_{2}\right.$ and $\left.\underline{\mathrm{CH}_{3}}\right), 1.68-1.75\left(\mathrm{~m}, 2 \mathrm{H}, \underline{\mathrm{C}}_{2}\right) ;{ }^{13} \mathrm{C}-\mathrm{NMR}\left(\mathrm{CDCl}_{3}\right): \delta_{\mathrm{C}}$ 170.9, 129.6, 128.6, 77.3, 72.1, 32.8, 30.0, 22.8, 22.8, 21.2. GC: Cromopack column $\mathrm{t}_{\mathrm{R}}=56.6 \mathrm{~min}$ HRMS: calcd for $\mathrm{C}_{8} \mathrm{H}_{14} \mathrm{O}_{2}\left[\mathrm{M}-\mathrm{CH}_{2} \mathrm{CO}\right]^{+}$: 142.09938, Found: 142.0993 (0 ppm).

\section{6. (1R,2R)-(Z)-2-Acetoxy-cyclooct-4-enyle Acetate (4a)}

Compound 4a was obtained as a colorless oil. $[\alpha]_{D}^{20}+81.0^{\circ}\left(c 1.00 \mathrm{CHCl}_{3}\right) \cdot v_{\max }\left(\mathrm{cm}^{-1}\right): 3016,2938$, 2866, 1732, 1654, 1431, 1370, 1226, 1244, 1032, 978, 946, 735, 722; ${ }^{1} \mathrm{H}-\mathrm{NMR}\left(\mathrm{CDCl}_{3}\right): \delta_{\mathrm{H}} 5.69-5.62$ $(2 \mathrm{H}, \mathrm{m}, \mathrm{C} \underline{\mathrm{H}}=\mathrm{C} \underline{\mathrm{H}}), 5.05-5.08(2 \mathrm{H}, \mathrm{m}, 2 \times \mathrm{C} \underline{\mathrm{HOH}}), 2.35-2.41\left(2 \mathrm{H}, \mathrm{m}, \underline{\mathrm{C}}_{2}\right), 2.12-2.18\left(2 \mathrm{H}, \mathrm{m}_{2} \mathrm{C}_{2}\right)$, 2.01-2.04 (2H, m, $\left.\underline{\mathrm{C}}_{2}\right), 1.96\left(\mathrm{~s}, 6 \mathrm{H}, 2 \times \mathrm{C}_{3}\right), 1.73-1.76\left(2 \mathrm{H}, \mathrm{m}, \mathrm{C}_{2}\right) .{ }^{13} \mathrm{C}-\mathrm{NMR}\left(\mathrm{CDCl}_{3}\right): \delta_{\mathrm{C}} 170.1$, 128.6, 73.6, 29.9, 22.7, 20.9; $[\alpha]_{\mathrm{D}}:+83.9^{\circ}\left(\mathrm{c}=1.00 \mathrm{CHCl}_{3}\right) \mathrm{GC}$ Cromopack column $\mathrm{t}_{\mathrm{R}}=61.2 \mathrm{~min}$.

\section{7. (1S,2S)-(Z)-2-Acetoxy-cyclooct-4-enyle acetate (4b)}

Compound $4 \mathbf{b}$ was obtained as a colorless oil; $[\alpha]_{D}^{20}-79.0^{\circ}\left(c 1.00 \mathrm{CHCl}_{3}\right) \cdot v_{\max }\left(\mathrm{cm}^{-1}\right): 3016,2938$, 2866, 1732, 1654, 1431, 1370, 1226, 1244, 1032, 978, 946, 735, 722; ${ }^{1} \mathrm{H}-\mathrm{NMR}\left(\mathrm{CDCl}_{3}\right): \delta_{\mathrm{H}} 5.69-5.62$ $(2 \mathrm{H}, \mathrm{m}, \mathrm{C} \underline{\mathrm{H}}=\mathrm{C} \underline{\mathrm{H}}), 5.05-5.08(2 \mathrm{H}, \mathrm{m}, 2 \times \underline{\mathrm{HOH}}), 2.35-2.41\left(2 \mathrm{H}, \mathrm{m}, \underline{\mathrm{C}}_{2}\right), 2.12-2.18\left(2 \mathrm{H}, \mathrm{m}, \mathrm{C}_{2}\right)$, 2.01-2.04 (2H, m, $\left.\underline{\mathrm{C}}_{2}\right), 1.96\left(\mathrm{~s}, 6 \mathrm{H}, 2 \times \mathrm{C}_{3}\right), 1.73-1.76\left(2 \mathrm{H}, \mathrm{m}, \mathrm{C}_{2}\right) .{ }^{13} \mathrm{C}-\mathrm{NMR}\left(\mathrm{DCl}_{3}\right): \delta_{\mathrm{C}} 170.1$, 128.6, 73.6, 29.9, 22.7, 20.9; GC: Cromapack column $t_{\mathrm{R}}=59.4 \mathrm{~min}$; HRMS calcd for $\mathrm{C}_{10} \mathrm{H}_{16} \mathrm{O}_{3}$ [M$\mathrm{CH}_{2} \mathrm{CO}^{+}:$184.10994, Found: 184.1091 (4 ppm). 
3.8. General Procedure for Enantioselective Acetylation of Racemic (Z)-Cyclooct-5-en-1,2-diol (2) Using Lipase

Under inert atmosphere, to a solution of racemic diol $2(0.2 \mathrm{~g}, 1.41 \mathrm{mmol})$ solubilized in $2.5 \mathrm{~mL}$ of THF were added the vinyl acetate $(1.3 \mathrm{~mL}, 14 \mathrm{mmol})$ and the appropriate immobilized lipase $(50 \mathrm{mg})$. The mixture was stirred at the required temperature under classical heating or microwave irradiation (see Tables 1-3). The mixture was filtrated, extracted with ethyl acetate $(3 \times 7 \mathrm{~mL})$. The organic layers were washed with $3 \mathrm{~mL}$ of $\mathrm{HCl} 5 \%, 3 \mathrm{~mL}$ of sodium hydrogenocarbonate, brine, dried with magnesium sulfate and concentrated under reduced pressure. The crude residue was purified by column chromatography (silica gel, petroleum ether/ethyl acetate $60 / 40)$ to give the $(1 R, 2 R)-(Z)$-1-hydroxycyclooct-4-enyl acetates $\mathbf{3 a}, \mathbf{3 b}, \mathbf{4 b}$.

\subsection{General Procedure for the Hydrolysis of (Z)-2-Acetoxy-cyclooct-4-enyle Acetate (4) by Candida} Antarctica Lipase B

Under inert atmosphere, to a solution of racemic (Z)-2-acetoxycyclooct-4-enyl acetate $4(0.2 \mathrm{~g}$, $0.88 \mathrm{mmol}$ ) in $2.5 \mathrm{~mL}$ of phosphate buffer $0.1 \mathrm{M}, \mathrm{pH}=7.0$, was added the lipase (50 $\mathrm{mg}$ ). The mixture was stirred at $50{ }^{\circ} \mathrm{C}$ under microwave irradiation (see Tables 4-6). The mixture was filtrated, extracted with ethyl acetate $(3 \times 7 \mathrm{~mL})$. The organic layers were washed with $3 \mathrm{~mL}$ of $\mathrm{HCl} 5 \%, 3 \mathrm{~mL}$ of sodium hydrogenocarbonate, brine, dried with magnesium sulfate and concentrated under reduced pressure. The crude residue was purified by column chromatography (silica gel, petroleum ether/ethyl acetate $60 / 40$ ) to give $\mathbf{3 a}, \mathbf{3 b}$ and $\mathbf{4 a}, \mathbf{4 b}$.

\subsection{Diacetate Enrichment}

The enriched (Z)-2-acetoxycyclooct-4-enyl compound 4a is solubilized in $2.5 \mathrm{~mL}$ of phosphate buffer $0.1 \mathrm{M}, \mathrm{pH}=7.0$. Candida antarctica lipase $\mathrm{B}(50 \mathrm{mg})$ was added and the mixture was stirred at $50{ }^{\circ} \mathrm{C}$ during $14 \mathrm{~h}$ by microwave irradiation (open vessel). The mixture was filtrated, extracted with ethyl acetate $(3 \times 7 \mathrm{~mL})$, The combined organic layers were washed with $3 \mathrm{~mL}$ of $\mathrm{HCl} 5 \%, 3 \mathrm{~mL}$ of sodium hydrogenocarbonate, brine, dried with magnesium sulfate and concentrated under reduced pressure. The crude residue was purified by chromatography column (silica gel, petroleum ether/ethyl acetate $60 / 40)$ to give the $(Z)-(1 S, 2 S)$-2-hydroxy-cyclooct-4-enyl acetate $\mathbf{3 b}$ in $49 \%$ overall yield $(0.098 \mathrm{~g}$, ee $>99 \%)$ and $4 \mathrm{a}$ in $51 \%$ overall yield $(0.083 \mathrm{~g}$, ee $>99 \%)$.

\subsection{Influence of the Power of the Microwave for the Acetylation of (Z)-Cyclooct-5-en-1,2-diol (2)}

The cryogenic fluid (Garlon $80^{\circledR}$ ) of the Coolmate ${ }^{\circledR}$ was cooled by dry ice, and maintained at $7{ }^{\circ} \mathrm{C}$. To a solution of racemic diol $2(0.2 \mathrm{~g}, 1.406 \mathrm{mmol})$ solubilized in $2.5 \mathrm{~mL}$ of THF was added vinyl acetate $(1.3 \mathrm{~mL}, 14 \mathrm{mmol})$ and Candida antarctica lipase $(50 \mathrm{mg})$. The mixture was irradiated with an internal temperature set to $35^{\circ} \mathrm{C}$, leading to an irradiation power of $300 \mathrm{~W}$. After $7 \mathrm{~h}$ of irradiation, the mixture was filtrated, extracted with ethyl acetate $(3 \times 7 \mathrm{~mL})$. The organic layers were washed with $3 \mathrm{~mL}$ of $\mathrm{HCl} 5 \%, 3 \mathrm{~mL}$ of sodium hydrogenocarbonate, brine, dried with magnesium sulfate and concentrated under reduced pressure. The crude residue was purified by column chromatography (silica gel, petroleum ether/ethyl acetate $60 / 40)$ to give the $(Z)-(1 R, 2 R)$-1-hydroxycyclooct-4-enyl 
acetate 3a in $42 \%$ yield $(0.108 \mathrm{~g}$, ee $=67 \%),(Z)-(1 S, 2 S)$-2-acetoxycyclooct-4-enyl acetate $\mathbf{4 b}$ in $2 \%$ yield $(\mathrm{ee}=99 \%)$ and $(Z)-$ cyclooct-5-en-1,2-diol in 51\% yield $(0.102 \mathrm{~g}$, ee $=50 \%)$.

\subsection{Synthesis of Diols by Saponification of Esters}

Under inert atmosphere, to a solution of enantiopure $(Z)-(1 R, 2 R)$-2-acetoxycyclooct-4-enyl acetate 4b $(0.2 \mathrm{~g}, 17.3 \mathrm{mmol})$ or enantiopure monoacetate $3 \mathbf{a}(0.2 \mathrm{~g}, 12.0 \mathrm{mmol})$ in methanol $(10 \mathrm{~mL})$ was added potassium carbonate anhydrous $(4 \mathrm{mg}, 0.86 \mathrm{mmol})$. The mixture was stirred $8 \mathrm{~h}$ at $0{ }^{\circ} \mathrm{C}$, and $10 \mathrm{~mL}$ of hydrochloric acid $1 \mathrm{M}$ are added. The aqueous layer was extracted with ethyl acetate $(3 \times 8 \mathrm{~mL})$, washed with a saturated solution of sodium hydrogenocarbonate $(5 \mathrm{~mL})$ and brine $(5 \mathrm{~mL})$. The organic layers were dried with magnesium sulfate, concentrated under reduced pressure.

\subsection{3. (1R,2R)-(Z)-Cyclooct-5-ene-1,2-diol (2a)}

The crude residue was purified by column chromatography (silica gel, petroleum ether/ethyl acetate $60 / 40)$ to give the $(Z)-(1 R, 2 R)$-cyclooct-5-ene-1,2-diol $\mathbf{2 a}\left(0.152 \mathrm{~g}, 99 \%\right.$ yield) as a white solid; $[\alpha]_{D}^{20}$ $-20.9^{\circ}\left(c 1,00 \mathrm{CHCl}_{3}\right) ; v_{\max }\left(\mathrm{cm}^{-1}\right): 3362,3014,2964,2861,1651,1427,1429,1400,1271,1202$, $1010,994,976,947,868,732,719 ;{ }^{1} \mathrm{H}-\mathrm{NMR}\left(\mathrm{CDCl}_{3}\right): \delta_{\mathrm{H}} 5.55-5.59(2 \mathrm{H}, \mathrm{m}, \mathrm{C} \underline{\mathrm{H}}=\mathrm{C} \underline{\mathrm{H}}), 3.57-3.61(\mathrm{~m}$, $4 \mathrm{H}, 2 \times \mathrm{CHO} \underline{\mathrm{H}}), 2.29-2.35\left(2 \mathrm{H}, \mathrm{m}, \mathrm{C}_{2}\right), 2.00-2.12\left(2 \mathrm{H}, \mathrm{m}, \mathrm{C}_{2}\right), 1.52-1.58\left(2 \mathrm{H}, \mathrm{m}, \mathrm{CH}_{2}\right) ;{ }^{13} \mathrm{C}-\mathrm{NMR}$ $\left(\mathrm{CDCl}_{3}\right): \delta_{\mathrm{c}} 128.9,73.8,33.1,22.6$; HRMS: calculated for $\mathrm{C}_{8} \mathrm{H}_{14} \mathrm{O}_{2}[\mathrm{M}]^{+}:$142.09938, Found: 142.1001 $(5 \mathrm{ppm})$. HPLC $\mathrm{t}_{\mathrm{R}}=11.9 \mathrm{~min}$.

\subsection{4. (1S,2S)-(Z)-Cyclooct-5-ene-1,2-diol (2b)}

The crude residue was purified by column chromatography (silica gel, petroleum ether/ethyl acetate $60 / 40)$ to give the $(Z)-(1 S, 2 S)$-cyclooct-5-en-1,2-diol $\mathbf{2 b}\left(0.153 \mathrm{~g}, 99 \%\right.$ yield) as a white solid. $[\alpha]_{D}^{20}$ $+18.2^{\circ}\left(\mathrm{c}=1,00 \mathrm{CHCl}_{3}\right) v_{\max }\left(\mathrm{cm}^{-1}\right): 3362,3014,2964,2861,1651,1427,1429,1400,1271,1202$, 1010, 994, 976, 947, 868, 732, 719; ${ }^{1} \mathrm{H}-\mathrm{NMR}\left(\mathrm{CDCl}_{3}\right): \delta_{\mathrm{H}} 5.55-5.59(2 \mathrm{H}, \mathrm{m}, \mathrm{C} \underline{\mathrm{H}}=\mathrm{C} \underline{\mathrm{H}}), 3.57-3.61(\mathrm{~m}$, $4 \mathrm{H}, 2 \times \mathrm{CHO} \underline{\mathrm{H}}), 2.29-2.35\left(2 \mathrm{H}, \mathrm{m}, \mathrm{CH}_{2}\right), 2.00-2.12\left(2 \mathrm{H}, \mathrm{m}, \underline{\mathrm{C}}_{2}\right), 1.52-1.58\left(2 \mathrm{H}, \mathrm{m}, \mathrm{CH}_{2}\right) ;{ }^{13} \mathrm{C}-\mathrm{NMR}$ $\left(\mathrm{CDCl}_{3}\right): \delta_{\mathrm{c}} 128.9,73.8,33.1,22.6$; HRMS: calculated for $\mathrm{C}_{8} \mathrm{H}_{14} \mathrm{O}_{2}[\mathrm{M}]^{+}:$142.09938, Found: 142.1001 $(5 \mathrm{ppm})$. HPLC $\mathrm{t}_{\mathrm{R}}=10.8 \mathrm{~min}$.

\section{Conclusions}

The kinetic resolution of homochiral (Z)-cyclooct-5-ene-1,2-diols and (Z)-2-acetoxycyclooct-4-enyl acetates has been accomplished controlled using two different lipases (CaLB or PS-D) in order to obtain one or the other useful enantiomer. The role of the microwave power has also been highlighted. Finally, by microwave irradiation, this eco-efficient optimization for the resolution of racemic diols, leads to a reduction of the reaction time and a decrease of power consumption, without any toxicity.

\section{Supplementary Materials}

Supplementary materials can be accessed at: http://www.mdpi.com/1420-3049/19/7/9230/s1. 


\section{Acknowledgments}

The authors would like to thank ANR EXPENANTIO, la "Ligue Nationale Contre le Cancer" for financial supports and the "Ministère de la Recherche et de l'Enseignement Supérieur" for grant (HR).

\section{Author Contributions}

Valérie Thiéry, Lisianne Domon, and Marianne Graber designed the research. Hervé Rouillard and Emmanuel Deau performed the experimental work and participated equally to this work and should be considered as primary co-authors. Valérie Thiéry wrote the manuscript with the cooperation of Emmanuel Deau and Hervé Rouillard. All authors discussed, edited and approved the submitted version.

\section{Conflicts of Interest}

The authors declare no conflict of interest.

\section{References}

1. Bornscheuer, U.T.; Kazlauskas, R.J. Hydrolases in Organic Synthesis, 2nd ed.; WILEY-VCH, Verlag GmbH \& Co. KGaA: Weinheim, Germany, 2006; pp. 61-184.

2. Gotor-Fernadez, V.; Brieva, R.; Gotor, V. Lipases: Useful biocatalysts for the preparation of pharmaceuticals. J. Mol. Cat. B 2006, 40, 111-120.

3. Pchelka, B.; Loupy, A.; Petit, A. Preparation of various enantiomerically pure (benzotriazol-1-yl)-and (benzotriazol-2-yl)-alkan-2-ols. Tetrahedron 2006, 17, 2516-2530.

4. Bachu, P.; Sperry, J.; Brimble, M. Synthesis of a C8 oxygenated pyranonaphthoquinone: A useful precursor to dimeric pyranonaphthoquinones. Tetrahedron 2008, 64, 3343-3350.

5. Leadbeater, N.; Stencel, L.M.; Wood, E.C. Probing the effects of microwave irradiation on enzyme-catalysed organic transformations: The case of lipase-catalysed transesterification reactions. Org. Biomol. Chem. 2007, 5, 1052-1055.

6. Parvulescu, A.N.; Jacobs, P.A.; de Vos, D.E. Support influences in the Pd-catalyzed racemization and dynamic kinetic resolution of chiral benzylic amines. Appl. Catal. A 2009, 368, 9-16.

7. De Souza, O.M.A.; Antunes, O.A.C.; Kroutil, W.; Kappe, C.O. Kinetic resolution of rac-1-phenylethanol with immobilized lipases: A critical comparison of microwave and conventional heating protocols. J. Org. Chem. 2009, 74, 6157-6162.

8. Yadav, G.D.; Pawar, S.V. Insight into microwave irradiation and enzyme catalysis in enantioselective resolution of DL-( \pm )-3-phenyllactic acid. Appl. Microbiol. Biotechnol. 2012, 96, 69-79.

9. Rouillard, H.; Chérouvrier J.R.; Thiéry, V. Biocatalysis Under microwave irradiation. In Ultrasound and Microwave: Recent Advances in Organic Chemistry, 1st ed.; Bazureau, J.P., Draye, M., Eds.; Transword Research Network: Kerala, India, 2011; pp. 175-214.

10. Bódai, V.; Orovecz, O.; Szakács, G.; Novák, L.; Poppe, L. Kinetic resolution of trans-2acetoxycycloalkan-1-ols by lipase-catalysed enantiomerically selective acylation. Tetrahedron: Asymmetry 2003, 14, 2605-2612. 
11. Onomura, O.; Arimoto, H.; Matsumura, Y.; Demizu, Y. Asymmetric oxidation of 1,2-diols using $\mathrm{N}$-bromosuccinimide in the presence of chiral copper catalyst. Tetrahedron Lett. 2007, 48, 8668-8672.

12. Demizu, Y.; Matsumoto, K.; Onomura, O.; Matsumura, Y. Copper complex catalyzed asymmetric monosulfonylation of meso-vic-diols. Tetrahedron Lett. 2007, 48, 7605-7609.

13. Wakita, N.; Hara, S. Selective mono-acylation of 1,2- and 1,3-diols using ( $\alpha, \alpha$-difluoroalkyl)amines. Tetrahedron 2010, 66, 7939-7945.

14. Suemune, H.; Hizuka, M.; Kamashita, T.; Sakai, K. Preparation of optically active $\gamma$-hydroxyethyl $\alpha, \beta$-unsaturated $\gamma$-lactone using an enzymatic procedure. Chem. Pharm. Bull. 1989, 37, 1379-1381.

15. Suemune, H.; Hasegawa, A.; Sakai, K. Highly enantio- and diastereo-seleetive synthesis of C2-symmetrie 3,5-cyclohexadiene-1,2-diol and D2-symmetric cyclohexane-1,2,4,5-tetrol. Tetrahedron 1995, 6, 55-58.

16. Mateo, C.; Palomo, J.M.; Fernandez-Lorente, G.; Fernandez-Lafuente R.; Guisan, J.M. Improvement of enzyme activity, stability and selectivity via immobilization techniques. Enzyme Microb. Technol. 2007, 40, 1451-1463.

17. Poojari, Y.; Clarson, S. Thermal stability of Candida antarctica lipase B immobilized on macroporous acrylic resin particles in organic media. Biocatal. Agric. Biotechnol. 2013, 2, 7-11.

18. Bachu, P.; Gibson, J.S.; Sperry, J.; Brimble, M.A. The influence of microwave irradiation on lipase-catalyzed kinetic resolution of racemic secondary alcohols. Tetrahedron 2007, 18, 1618-1624.

19. Horikawa, T.; Norimine, Y.; Tanaka, M.; Sakai, K.; Suemune, H. Synthesis of optically active bicyclo[3.3.0] octane skeleton using transannular reaction. Chem. Pharm. Bull. 1998, 46, 17-21.

Sample Availability: Samples of the compounds $\mathbf{2 a}, \mathbf{2 b}, \mathbf{3 a}, \mathbf{3 b}, \mathbf{4} \mathbf{a}$ and $\mathbf{4 b}$ are available from the authors.

(C) 2014 by the authors; licensee MDPI, Basel, Switzerland. This article is an open access article distributed under the terms and conditions of the Creative Commons Attribution license (http://creativecommons.org/licenses/by/3.0/). 